\title{
Patterns of circulating serotonin and related metabolites in multiparous dairy cows in the peripartum period
}

\author{
S. A. E. Moore, ${ }^{*}$ J. Laporta, ${ }^{*}$ T. D. Crenshaw, $\dagger$ and L. L. Hernandez ${ }^{* 1}$ \\ ${ }^{*}$ Department of Dairy Science, and \\ †Department of Animal Science, University of Wisconsin-Madison, Madison 53706
}

\begin{abstract}
Dairy cows are challenged to maintain $\mathrm{Ca}$ and glucose homeostasis during the transition period. Serotonin $(5-\mathrm{HT})$ is a monoamine that modulates $\mathrm{Ca}$ and glucose homeostasis in rodents. Serotonin is positively correlated with $\mathrm{Ca}$ and glucose status in dairy cows on d 1 of lactation. However, the pattern of circulating concentrations of 5-HT over the course of a 305-d lactation is unknown. In this observational, longitudinal study, we examined the metabolite patterns of 5-HT, $\mathrm{Ca}$, glucose, parathyroid hormone-related protein, and $\beta$-hydroxybutyrate on 2 commercial dairy farms in south-central Wisconsin. Cows sampled on farm 1 were multiparous Jersey cows $(\mathrm{n}=30)$ that calved within a 23-d period; cows on farm 2 were multiparous Holstein cows $(\mathrm{n}=35)$ that calved within a $20-\mathrm{d}$ period. Blood samples were collected daily between $\mathrm{d}-5$ and $\mathrm{d} 10$ relative to parturition and on d 30,60,90, 150, and 300 of lactation. Farms 1 and 2 were analyzed individually because of the presence of a farm effect in the initial analysis; a time effect was present on both farms. Concentrations of 5-HT decreased near parturition compared with prepartum by 57.9 and $29.5 \%$ on farm 1 and 2 , respectively. Transition period 5-HT nadirs were observed on d 1 on farm 1 , and on d 1 and 9 on farm 2 . Serotonin recovered to prepartum concentrations by $\mathrm{d}$ 5 on farm 1 . On farm 2, 5 -HT recovered to prepartum concentrations by $\mathrm{d} 4$, with a subsequent decrease of $34.6 \%$ on $\mathrm{d} 9$ to a level similar to that observed on $\mathrm{d}$ 1. Furthermore, 5-HT increased markedly in cows on both farms near peak lactation (d 60, 90, and 150) and decreased on d 300. Compared with prepartum concentrations, $\mathrm{Ca}$ decreased by 34.2 and $11.2 \%$ on farms 1 and 2, respectively. Circulating total $\mathrm{Ca}$ nadir was observed on d 1 on both farms. Circulating 5-HT and circulating $\mathrm{Ca}$ were positively correlated during the early lactation period (d 1 to 5 and d 6 to 10) on farm
\end{abstract}

Received September 10, 2014.

Accepted February 23, 2015.

${ }^{1}$ Corresponding author: llhernandez@wisc.edu $1(\mathrm{r}=0.31$ and $\mathrm{r}=0.22$, respectively) and $\mathrm{d} 6$ to 10 on farm $2(\mathrm{r}=0.16)$. Circulating 5 -HT and glucose were negatively correlated during the early lactation period ( 1 to 5$)$ on farm $1(\mathrm{r}=-0.21)$ and during mid-lactation (d 30 to 150) on farm 2 ( $\mathrm{r}=-0.26$ ). Milk 5-HT and milk total Ca were positively correlated on farm $2(\mathrm{r}=0.34)$. These results demonstrate that 5-HT concentrations change dynamically throughout the transition period, with a pattern similar to that of total Ca concentrations. Further research using controlled experiments should be aimed at discerning the association between 5-HT and $\mathrm{Ca}$ and between 5-HT and glucose in dairy cows.

Key words: calcium, lactation, hypocalcemia, serotonin

\section{INTRODUCTION}

Dairy cows are challenged to maintain $\mathrm{Ca}$ and glucose homeostasis during the transition period. The transition period is defined as 3 wk prepartum through 3 wk postpartum (Grummer, 1995). Subclinical hypocalcemia (total blood $\mathrm{Ca}=1.4-2.0 \mathrm{mM}$ ) affects $25 \%$ of primiparous and $47 \%$ of multiparous cows postpartum. In addition, clinical hypocalcemia (total blood $\mathrm{Ca}$ $<1.4 \mathrm{mM}$ ) is observed in 5 to $10 \%$ of all dairy cows (Reinhardt et al., 2011). Hypocalcemia is associated with an increased risk of production losses, displaced abomasum, metritis, reproductive deficiencies, and ketosis (Adams et al., 1996). Jersey cows have a 2.25 times greater risk of developing hypocalcemia than Holstein cows (Lean et al., 2006). In addition, milk from Jersey cows contains approximately $36 \%$ more Ca than Holstein milk (Czerniewicz et al., 2006).

Serotonin (5-hydroxytryptamine; 5 -HT) is a monoamine that modulates $\mathrm{Ca}$ and glucose homeostasis in rodents (Laporta et al., 2013a,b). Serotonin mediates numerous processes in the mammary gland, including tight junction permeability, parathyroid hormonerelated protein (PTHrP) production, and $\mathrm{Ca}$ and glucose transporter expression (Matsuda et al., 2004; Stull et al., 2007; Hernandez et al., 2012; Laporta et al., 2013a,b). Serotonin and PTHrP are known activators 
of the cytokine receptor activator of nuclear factor- $\mathrm{B}$ ligand pathway (Hernandez et al., 2012). Activation of this pathway increases bone demineralization and $\mathrm{Ca}$ resorption to meet demands when circulating Ca levels are insufficient (Wysolmerski, 2002, 2010; ChabbiAchengli et al., 2012).

Feeding a 5-HT precursor, 5-hydroxytryptophan, increased osteoclast number and size, as well as serum total Ca concentrations in a murine model (Laporta et al., 2013b). Parathyroid hormone-related protein concentrations were also increased. Serotonin may regulate glucose homeostasis, as liver mRNA expression of gluconeogenic and glycolytic enzymes were greater in 5-hydroxytryptophan-supplemented animals (Laporta et al., 2013a). On d 1 of lactation, 5-HT was positively correlated with $\mathrm{Ca}$ and $\mathrm{PTHrP}$ concentrations and negatively correlated with ketosis severity in dairy cows (Laporta et al., 2013c).

The potential use of 5-HT in the dairy industry is an exciting possibility. However, 5 -HT has not been evaluated temporally in the dairy cow to date. To effectively study 5 -HT in dairy cows, the temporal changes that occur in dairy cows not subjected to treatment need to be established. Therefore, the experiment herein was designed as a longitudinal observational study in multiparous Jersey and Holstein dairy cows maintained on 2 dairy farms in south-central Wisconsin. The results obtained from this experiment will be used to design and conduct future experiments that use 5-HT as a modulator of transition-related health issues in dairy cows as a method to improve the well-being and profitability of dairy cows.

\section{MATERIALS AND METHODS}

The College of Agriculture and Life Sciences Animal Care and Use Committee at the University of Wisconsin-Madison approved all experimental procedures used on animals in this study. All protocol (A01489) guidelines for the care and use of animals were strictly followed.

\section{Animals}

Multiparous cows were housed on 2 privately owned commercial dairy farms in south central Wisconsin. Farm 1 housed multiparous Jersey animals $(\mathrm{n}=30$; mean parity $=3.2$; average daily milk yield $=30.3$ $\mathrm{kg}$; daily ECM yield $=39.0 \mathrm{~kg}$ ). Breakdown of cows by parity were as follows: second lactation (7), third lactation (16), fourth lactation (4), sixth lactation (2), and seventh lactation (1). Cows were housed in a compost bedding pack barn until d 5 postpartum and then housed in a freestall barn through the remainder of the trial. A TMR formulated to meet or exceed NRC recommendations (NRC, 2001) was fed once daily at 0700 $\mathrm{h}$ throughout the experiment and animals had ad libitum access to water. The prefresh ration on this farm was formulated as a $41 \%$ forage (corn silage, grass hay, alfalfa haylage) to $59 \%$ concentrate (oat hulls, soy hulls, canola meal, corn distillers, mineral-protein mix) ratio with a DCAD of $1.127 \mathrm{mEq} / 100 \mathrm{~g}$ of DM. Cows were milked twice daily at 0500 and $1700 \mathrm{~h}$ during lactation.

Farm 2 housed Holstein cows. Multiparous cows (n $=35$; mean parity $=2.8$; average daily milk yield $=$ $47.2 \mathrm{~kg}$; daily ECM yield $=48.9 \mathrm{~kg}$ ) were housed in a freestall barn through the entirety of the trial. Breakdown of cows by parity were as follows: second lactation (20), third lactation (8), fourth lactation (3), fifth lactation (3), and sixth lactation (1). Cows were fed a TMR formulated to meet or exceed NRC recommendations (NRC, 2001) once daily at $0800 \mathrm{~h}$ throughout the experiment and animals had ad libitum access to water. The prefresh ration on this farm was formulated as a $41 \%$ forage (corn silage, alfalfa haylage, straw) to $58 \%$ concentrate (malt sprouts, wet molasses, mineral protein mix) ratio with a DCAD of $-11 \mathrm{mEq} / 100 \mathrm{~g}$ of DM. The DM target was $14 \mathrm{~kg}$ of feed per day. Cows were milked 3 times daily at 0400, 1200, and $2000 \mathrm{~h}$ during lactation.

Enrollment in the study began on farm 1 on January 22, 2013, and on farm 2 on February 13, 2013. Cows calved within a $23-\mathrm{d}$ and $20-\mathrm{d}$ period on farm 1 and farm 2, respectively. Animals on both dairies were appropriately treated for disease symptoms (i.e., hypocalcemia, ketosis, mastitis) when intervention was deemed necessary by the farm staff, and all animals were included in the study unless they left the herd before conclusion of the study.

\section{Blood and Milk Samples}

Blood serum and plasma samples were harvested from blood collected via the coccygeal vein on $\mathrm{d}-5$, $-4,-3,-2,-1,0,1,2,3,4,5,6,7,8,9$, and 10 , relative to parturition (DRTP). Samples were also collected on d $30 \pm 2$, d $60 \pm 2$, d $90 \pm 2$, d $150 \pm 2$, and d $300 \pm 2$ DRTP. Collection took place immediately following the time of first milking of the stated day for both dry and lactating cows. Whole blood for serum harvest was collected in an evacuated $10-\mathrm{mL}$ Clot Activator BD Vacutainer Serum Plus Blood Collection Tubes (367820, Becton Dickinson and Co., Franklin Lakes, NJ). Whole blood taken for plasma harvest was collected in an evacuated 10-mL BD Vacutainer with lithium heparin (367880, Becton Dickinson and Co.). 
Blood samples were stored at $4^{\circ} \mathrm{C}$ and transported back to the laboratory. Upon return, samples underwent centrifugation at $3,000 \times g$ for $20 \mathrm{~min}$ at $4^{\circ} \mathrm{C}$. Blood serum and plasma fractions were aliquoted and stored at $-80^{\circ} \mathrm{C}$ until analysis.

Milk was collected from all cows following preparatory treatment in the parlor facility. Milk was stripped directly from the teat into $88.7-\mathrm{mL}$ polypropylene sample vials. Samples were stored at $4^{\circ} \mathrm{C}$ and transported back to the laboratory. Samples were then stored at $-80^{\circ} \mathrm{C}$ until analysis.

\section{Laboratory Analysis}

Samples collected on all days from -5 to 300 DRTP were analyzed for blood serum 5-HT and total Ca concentrations. Blood plasma collected on all days from -5 to 300 DRTP was analyzed for glucose concentration. Blood serum 5-HT was measured using the Serotonin Enzyme Immunoassay kit (IM1749, Immunotech, Beckman Coulter, Marseille Cedex 9, France). The assay was conducted per the manufacturer's instructions except the blood serum was diluted 1:100 for sample values to fall within the standard curve of the assay. An identical pooled serum sample was included on all plates analyzed. The assay sensitivity was $0.088 \mathrm{ng} / \mathrm{mL}$, intraassay coefficient of variation (CV) was $4.34 \%$, and interassay CV was $15.9 \%$. Serum Ca was analyzed using the Calcium Assay kit (700550, Cayman Chemical, Ann Arbor, MI) per the manufacturer's instructions. An identical pooled serum sample was included on all plates analyzed. Total Ca assay sensitivity was 0.125 $\mathrm{m} M$, intraassay $\mathrm{CV}$ was $3.6 \%$, and interassay $\mathrm{CV}$ was $9.5 \%$. Blood plasma samples were analyzed for all days from d -5 to 300 for circulating plasma glucose concentration. Serum glucose was evaluated with the Glucose Plate Assay (Karkalas, 1985). An identical pooled plasma sample was included on all plates analyzed. The intraassay CV for the glucose assay was $2.0 \%$, and the interassay $\mathrm{CV}$ was $4.1 \%$.

Milk 5-HT (d 0 to 4) was measured using the same method as described above. The assay was conducted per the manufacturer's instructions except the milk was diluted 1:5 for sample values to fall within the standard curve of the assay. An identical pooled milk sample was included on all plates analyzed. The intraassay $\mathrm{CV}$ was $6.61 \%$ and the interassay CV was $16.7 \%$.

Blood serum BHBA (d 4 to 6) was measured using Autokit 3-HB Cyclic Enzymatic Method (41773501/413-73601, Wako Diagnostics, Richmond, VA) per the manufacturer's instructions, except the blood serum samples were diluted 1:14 in $0.9 \%$ sodium chloride injection saline solution (Hospira Inc., Lake Forest, IL). A serial dilution of Ketone Body Calibrator 300 re- agent (412-73791, Wako Diagnostics) was conducted to create a standard curve. Sodium chloride $(0.9 \%)$ saline solution was used as the diluent. An identical pooled serum sample was included on all plates analyzed. The assay sensitivity was within $\pm 10 \%$ known concentration, intraassay CV was $5.04 \%$, and interassay CV was $8.93 \%$.

All assays for blood serum and milk 5-HT, blood serum total Ca, blood serum BHBA, and blood plasma glucose were conducted in 96-well plates and read with a SpectraMAX 190 Absorbance Microplate Reader (Molecular Devices, Sunnyvale, CA).

Blood plasma samples for d -1 to 5 and d 300 were evaluated for circulating PTHrP concentrations. Plasma PTHrP was measured by the PTHrP immunoradiometric assay kit (DSL8100, Immunotech, Beckman Coulter, Prague, Czech Republic) per the manufacturer's instructions. Gamma ray count was measured using Cobra II Auto-Gamma (Packard BioScience Company, Meriden, CT). An identical pooled plasma sample was included in all assays conducted. The analytical sensitivity of the assay was $0.86 \mathrm{p} M$, functional sensitivity of the assay was $1.02 \mathrm{p} M$, intraassay $\mathrm{CV}$ was $3.70 \%$, and interassay CV was $21.68 \%$.

Total milk Ca concentrations were measured after an aliquot of each sample was digested in a nitric-perchloric acid solution $(3: 1 \mathrm{vol} / \mathrm{vol})$ and diluted with lanthanum chloride solution $(2,000 \mu \mathrm{g}$ of $\mathrm{La} / \mathrm{mL})$ as previously described (Rortvedt and Crenshaw, 2012; Laporta et al., 2014). Calcium concentration in the digest was measured using atomic absorption spectroscopy (model 2280, Perkin-Elmer Corp., Norwalk, CT). A pooled milk sample was spiked with $1.428 \mathrm{mg}$ of $\mathrm{Ca}$ per $\mathrm{mL}$ of sample, and percentage recovery was calculated to ensure that milk total Ca was accurately quantified. The digestion and analysis of spiked samples resulted in an average Ca recovery of $97.74 \%$. The intraassay CV was $0.79 \%$.

\section{Statistical Analysis}

A linear mixed model with repeated measures was used for analysis of data in this study. Each farm was evaluated individually with respect to the metabolites of interest over time with the following model because the initial analysis in which farm was included in the model as a fixed effect resulted in a significant farm effect:

$$
\mathrm{Y}_{\mathrm{ij}}=\mathrm{t}_{\mathrm{i}}+\mathrm{c}_{\mathrm{j}}+\varepsilon_{\mathrm{ij}},
$$

where $Y_{\mathrm{ij}}$ is the response for the ith DRTP for the jth cow. The fixed effect is time (t). Random effect of cow 
(c) was entered to account for between-cow error; $\varepsilon_{\mathrm{ij}}$ is the random error associated with the jth cow on the ith DRTP. Cow was entered as the repeated measure over time.

Each metabolite was evaluated for outliers, extreme influential data points, and normality. When necessary, outliers and extreme influential data points were removed, and nonparametric rank transformations were conducted to correct for normality. All Pearson correlation coefficients were calculated using the corrected data set. Mean values for each day are reported as the least squares means \pm standard error of the least squares means. Day-to-day comparisons are reported as the $t$-test statistic associated with the difference of the least squares means of the data minus outliers and extreme influential points.

Data were analyzed using PROC MIXED, rank transformations were conducted using PROC UNIVARIATE, and Pearson correlation coefficients were determined using PROC CORR with SAS software (version 9.3; SAS Institute Inc., Cary, NC). Statistical significance was declared at $P \leq 0.05$ and statistical tendencies at $0.05<P \leq 0.10$.

\section{RESULTS}

\section{Blood Serum Serotonin}

On farm 1 , cows exhibited no time effect from d -5 to -1 for circulating 5 -HT concentrations $(P \geq 0.35)$. A $57.9 \%$ decline in serum circulating 5 -HT occurred from peak prepartum (d -3) to 5 -HT nadir postpartum (d 2; 2,063 \pm 236 to $869 \pm 232 \mathrm{ng} / \mathrm{mL} ; P<0.0001 ;$ Figure 1A, Table 1). Circulating 5 -HT recovered to 1,629 $\pm 229 \mathrm{ng} / \mathrm{mL}$ on $\mathrm{d} 5(P=0.004)$ compared with the transition period nadir (d 2; Table 1). No time effect was observed between d 5 and $7(P=0.17$; Table 1$)$. Circulating serum 5-HT concentrations increased from d 7 to $10(1,215 \pm 222$ to $2,005 \pm 222 \mathrm{ng} / \mathrm{mL} ; P=$ 0.004; Figure 1A, Table 1). No time effect was observed between $\mathrm{d} 10$ and other posttransition measurement days $(P \geq 0.10)$. Peak 5 -HT concentration was achieved on d $150(2,463 \pm 222 \mathrm{ng} / \mathrm{mL}$; Table 1$)$. On d 300, a significant decline in circulating 5-HT was observed compared with that at $d 30,60,90$, and $150(P \leq 0.04)$. The 21 measurements taken throughout the lactation resulted in an average blood serum 5-HT concentration of $1,749 \pm 100 \mathrm{ng} / \mathrm{mL}$.

On farm 2, no time effect was observed from d -5 to -1 for circulating 5 -HT concentrations $(P \geq 0.18)$. Circulating blood serum 5-HT decreased $29.5 \%$ from peak prepartum $(\mathrm{d}-1)$ to $\mathrm{d} 1(1,512 \pm 173$ to $1,067 \pm$ $175 \mathrm{ng} / \mathrm{mL} ; P<0.04$; Figure 1B, Table 2). Circulat- ing concentrations of 5 -HT recovered to $1,575 \pm 186$ $\mathrm{ng} / \mathrm{mL}$ on d 4 compared with d $1(1,575 \pm 173 \mathrm{ng} /$ $\mathrm{mL} ; P=0.02$; Table 2). Transition period nadir was observed on d $9(1,021 \pm 175 \mathrm{ng} / \mathrm{mL})$; however, this value was not different from that on $\mathrm{d} 1$ (Table 2). A significant increase in circulating 5-HT concentrations was observed on d 60,90, and 150 compared with that on $\mathrm{d}-5$ through $30(P=0.03)$. Serotonin reached a peak concentration of $2,907 \pm 187 \mathrm{ng} / \mathrm{mL}$ on d 150 (Table 2). At the end of lactation (d 300), 5-HT decreased significantly from that on all other days to $517 \pm 200 \mathrm{ng} / \mathrm{mL}(P \leq 0.0324)$. The 21 measurements taken throughout lactation resulted in an average blood serum 5-HT concentration of 1,490 $\pm 89 \mathrm{ng} / \mathrm{mL}$.

\section{Blood Serum Ca}

Circulating total $\mathrm{Ca}$ concentrations predictably decreased near the time of parturition on both farms. On farm 1, circulating total $\mathrm{Ca}$ decreased significantly at the time of parturition $(P<0.0001)$ from prepartum concentrations. Postpartum Ca nadir occurred on $\mathrm{d}$ $1(1.79 \pm 0.07 \mathrm{mM})$ and was $34.2 \%$ lower than the peak prepartum circulating total $\mathrm{Ca}$ concentration recorded on $\mathrm{d}-2(2.72 \pm 0.07 \mathrm{~m} M$; Figure $1 \mathrm{~A}$, Table 1). Circulating total $\mathrm{Ca}$ on $\mathrm{d} 1$ was within the range of subclinical hypocalcemia $(1.4-2.0 \mathrm{mM})$. Circulating total Ca concentrations were elevated on d 3 compared with d 1 nadir $(2.27 \pm 0.07 \mathrm{mM} ; P=0.004)$. A daily increase occurred on d 4 and 5 relative to the measurement of the previous days $(P=0.0407$ and $P=0.0092$, respectively; Figure 1A, Table 1). Another significant increase was observed on d $9(2.74 \pm 0.07 \mathrm{mM} ; P=$ 0.028 ), relative to $d 7$ and 8 concentrations (Table 1 ). No time effect was observed between d 10 and any of the posttransition measurement days $(P \geq 0.50)$ except for a tendency relative to d $150(P=0.08)$. Peak circulating total Ca was observed on d 60 and 150 (2.85 土 $0.07 \mathrm{~m} M$; Table 1). A significant decrease in total $\mathrm{Ca}$ occurred on d 300 compared with d $150(2.69 \pm 0.08$ $\mathrm{m} M ; P=0.03 ;$ Table 1$)$.

On farm 2, Ca postpartum nadir was observed on d $1(2.29 \pm 0.05 \mathrm{mM}$; Table 2$)$. This was an $11.2 \%$ reduction from prepartum peak observed on $\mathrm{d}-3(2.72 \pm$ $0.07 \mathrm{~m} M ; P<0.0001 ;$ Figure 1B, Table 2). Circulating total Ca levels on farm 2 increased on $\mathrm{d} 3$ relative to $\mathrm{d}$ 1 nadir (2.43 $\pm 0.05 \mathrm{mM} ; P=0.03$; Table 2$)$. Day 10 total $\mathrm{Ca}$ was significantly greater than concentrations observed on d 1 through $6(P=0.04)$. No time effect was observed between d 10 and d 30,60, or $90(P \geq$ 0.46). Peak circulating total $\mathrm{Ca}$ on $\mathrm{d} 150$ was greater than all previous measurements from $\mathrm{d}-5$ through 90 $(2.68 \pm 0.05 \mathrm{~m} M ; P=0.05$; Table 2$)$. 

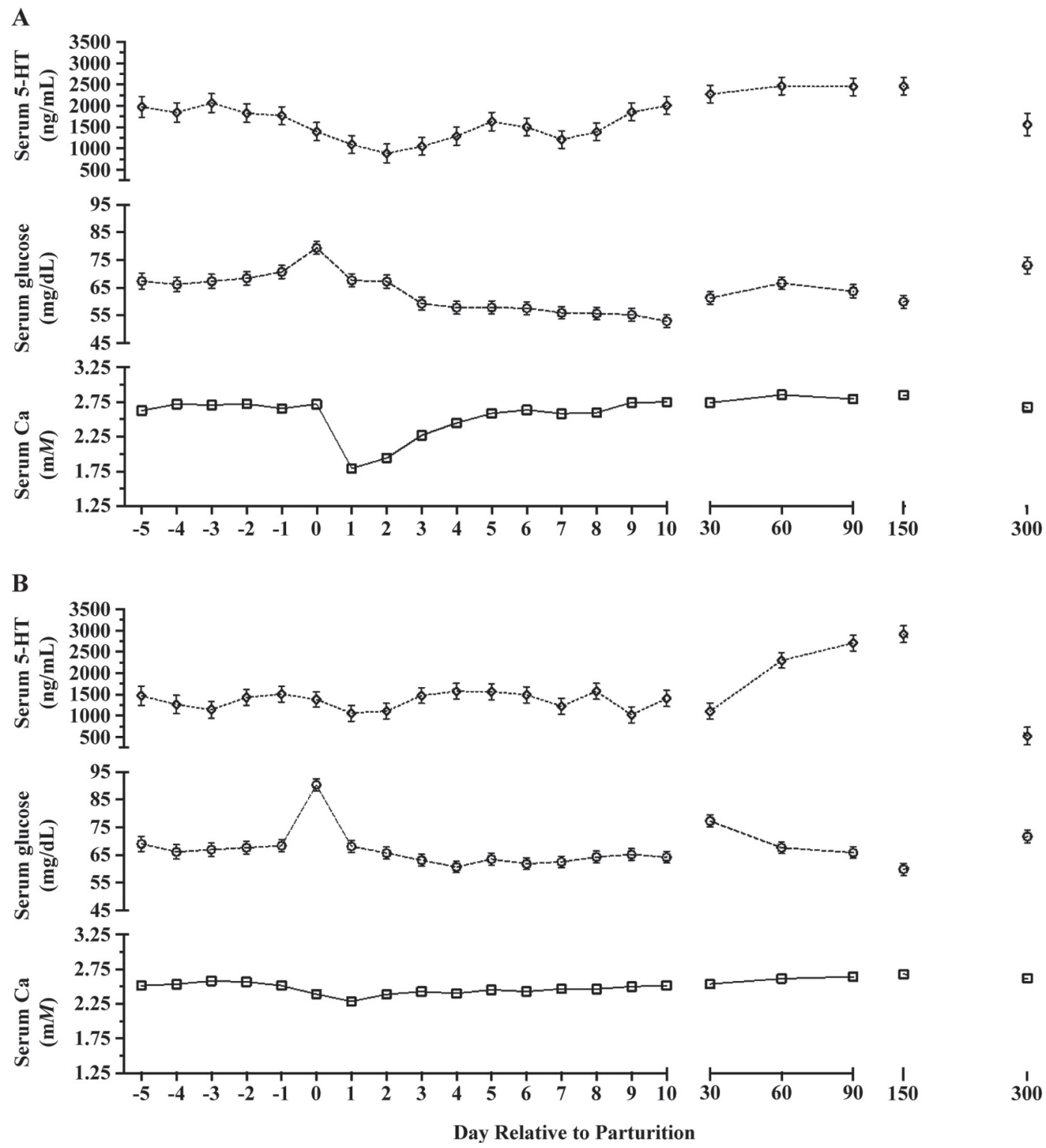

Figure 1. Patterns of serum serotonin (5-HT), serum total Ca, and plasma glucose in lactating dairy cows. (A) Farm 1: Serum 5-HT decreased near parturition compared with prepartum $57.9 \%(P<0.0001)$. Transition period 5 -HT nadir was observed on d $2(869 \pm 232 \mathrm{ng} /$ $\mathrm{mL}$ ); circulating 5 -HT recovered to $1,629 \pm 229 \mathrm{ng} / \mathrm{mL}$ by d 5 . Cows on farm 1 exhibited a significant increase in plasma glucose on the day of parturition (d 0), where concentrations reached $75.17 \pm 1.78 \mathrm{mg} / \mathrm{dL}$; the concentration on $\mathrm{d} 0$ was higher than on all other days measured $(P$ $\leq 0.04$ ) except $\mathrm{d}-2$ and $\mathrm{d} 300$. A decline in circulating plasma glucose occurred during the transition period, with the nadir occurring on $\mathrm{d} 10$ $(53.02 \pm 1.71 \mathrm{mg} / \mathrm{dL})$, at a concentration less $(P \leq 0.04)$ than that on all days measured excluding d 7 to $9(P \leq 0.11)$. Serum Ca decreased $34.2 \%(P<0.0001)$ compared with prepartum levels; the Ca nadir was observed on d $1(1.79 \pm 0.07 \mathrm{~m} M)$. (B) Farm 2: serum 5-HT decreased near parturition compared with prepartum $29.5 \%(P<0.03)$. Transition period 5-HT nadir was observed on d $9(1,021 \pm 175 \mathrm{ng} / \mathrm{mL})$; circulating 5 -HT recovered to $1,575 \pm 173 \mathrm{ng} / \mathrm{mL}$ by d 4 . Cows on farm 2 exhibited a significant increase in plasma glucose on the day of parturition (d 0). Plasma glucose reached $82.71 \pm 2.14 \mathrm{mg} / \mathrm{dL}$ on $\mathrm{d} 0$, a concentration that was greater $(P \leq 0.03)$ than on all other days excluding $\mathrm{d} 30$ and $300(P \geq 0.22)$. A decline occurred in circulating plasma glucose during the transition period from d 0 to nadir on $\mathrm{d} 4$ (60.68 $\pm 2.08 \mathrm{mg} /$ $\mathrm{dL} ; P<0.0001)$. Serum Ca decreased $11.2 \%(P<0.0001)$ compared with prepartum levels; the serum Ca nadir was observed on d $1(2.29 \pm$ $0.05 \mathrm{~m} M)$. Error bars represent SEM.

\section{Blood Plasma Glucose}

Circulating plasma glucose concentrations changed dynamically throughout the lactation cycle period on both farms 1 and 2. Plasma glucose concentrations surged on the day of parturition on both farms (Figure 1). Subsequently, both farms also saw a decline in circulating plasma glucose levels postpartum (Figure 1, Tables 1 and 2). This was consistent with the inability of the animals to maintain circulating plasma glucose 
Table 1. Metabolites (LSM \pm SEM) of interest on farm $1^{1}$

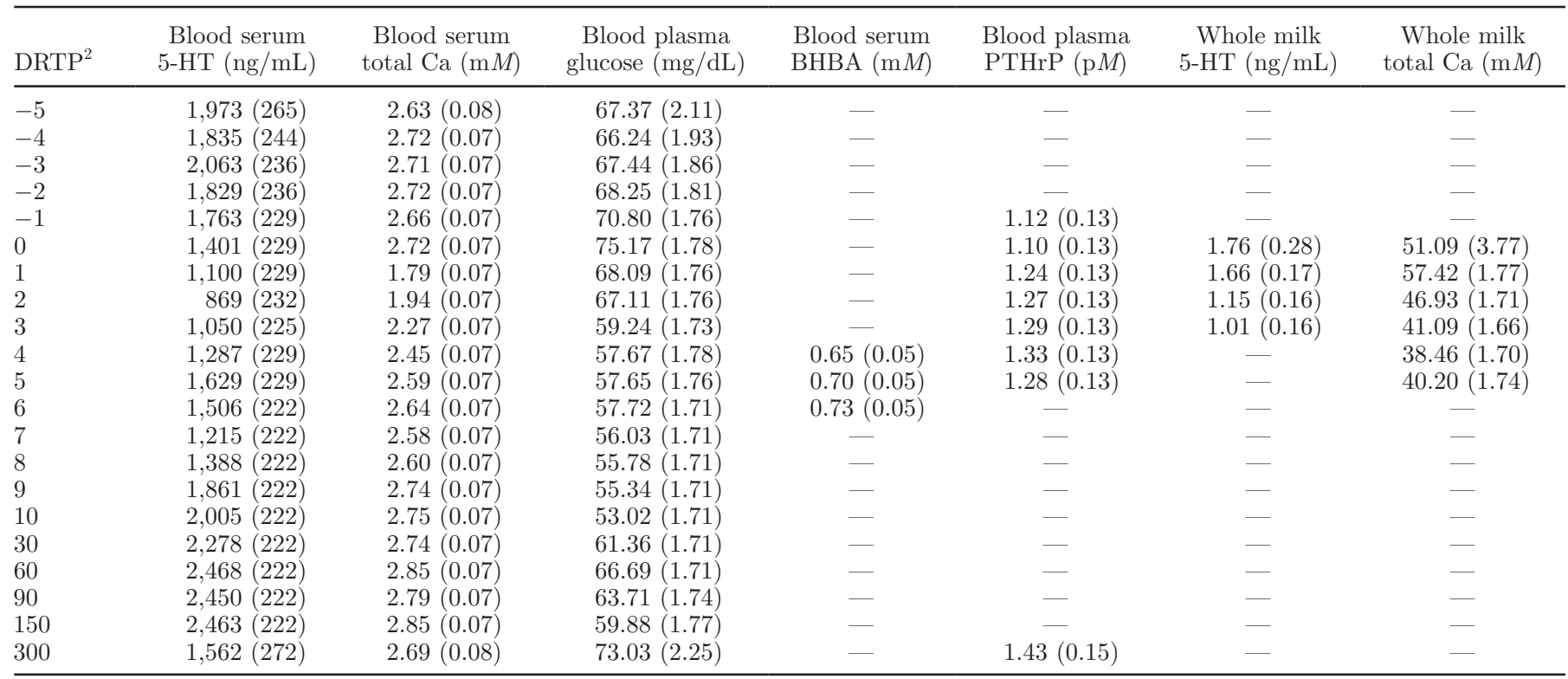

${ }^{1} 5$-HT $=$ serotonin (5-hydroxytryptamine); PTHrP = parathyroid hormone-related protein.

${ }^{2} \mathrm{DRTP}=$ day relative to parturition \pm 0 for $\mathrm{d}-5$ to $10 ; \pm 2$ for $\mathrm{d} 30,60,90,150$, and 300.

levels postpartum and achieving a negative energy balance.

Farm 1 had a peak circulating plasma glucose concentration of $75.17 \pm 1.78 \mathrm{mg} / \mathrm{dL}$ on $\mathrm{d} 0$ and this was greater than all days measured $(P \leq 0.04)$ except $\mathrm{d}-2$ $(P=0.05)$ and $\mathrm{d} 300(P=0.75$; Table 1$)$. A precipitous decline characterized the remainder of the transition period. Glucose nadir was observed on d 10 (53.02 \pm $1.71 \mathrm{mg} / \mathrm{dL}$; Figure $1 \mathrm{~A})$ and was less than on all days measured $(P \leq 0.04)$ excluding d 7 through $9(P \geq$ 0.11 ; Table 1). Circulating plasma glucose concentrations fluctuated throughout the remainder of the lactation. Glucose concentrations were greater on d 30 than on d $10(61.36 \pm 1.71 \mathrm{mg} / \mathrm{dL} ; P=0.0009$; Table 1$)$.

Table 2. Metabolites (LSM \pm SEM) of interest on farm $2^{1}$

\begin{tabular}{|c|c|c|c|c|c|c|c|}
\hline DRTP $^{2}$ & $\begin{array}{l}\text { Blood serum } \\
\text { 5-HT (ng/mL) }\end{array}$ & $\begin{array}{l}\text { Blood serum } \\
\text { total Ca }(\mathrm{m} M)\end{array}$ & $\begin{array}{c}\text { Blood plasma } \\
\text { glucose }(\mathrm{mg} / \mathrm{dL})\end{array}$ & $\begin{array}{l}\text { Blood serum } \\
\text { BHBA }(\mathrm{m} M)\end{array}$ & $\begin{array}{l}\text { Blood plasma } \\
\text { PTHrP }(\mathrm{p} M)\end{array}$ & $\begin{array}{l}\text { Whole milk } \\
\text { 5-HT (ng/mL) }\end{array}$ & $\begin{array}{l}\text { Whole milk } \\
\text { total Ca }(\mathrm{m} M)\end{array}$ \\
\hline-5 & $1,478(220)$ & $2.52(0.06)$ & $69.26(2.72)$ & - & - & - & - \\
\hline-4 & $1,268(210)$ & $2.53(0.05)$ & $66.27(2.54)$ & - & - & - & - \\
\hline-3 & $1,161(188)$ & $2.58(0.05)$ & $67.03(2.35)$ & - & - & - & - \\
\hline-2 & $1,437(176)$ & $2.57(0.05)$ & $67.65(2.20)$ & - & - & - & - \\
\hline-1 & $1,512(173)$ & $2.52(0.05)$ & $68.43(2.11)$ & - & $1.26(0.12)$ & - & - \\
\hline 0 & $1,387(173)$ & $2.39(0.05)$ & $82.71(2.14)$ & - & $1.30(0.12)$ & $6.13(0.39)$ & $59.88(1.66)$ \\
\hline 1 & $1,067(175)$ & $2.29(0.05)$ & $68.14(2.08)$ & - & $1.30(0.12)$ & $3.47(0.34)$ & $55.46(1.40)$ \\
\hline 2 & $1,110(173)$ & $2.39(0.05)$ & $65.75(2.11)$ & - & $1.65(0.12)$ & $2.44(0.33)$ & $42.55(1.37)$ \\
\hline 3 & $1,476(173)$ & $2.43(0.05)$ & $63.14(2.08)$ & - & $1.45(0.13)$ & $1.94(0.34)$ & $37.32(1.41)$ \\
\hline 4 & $1,575(173)$ & $2.40(0.05)$ & $60.68(2.08)$ & $0.74(0.07)$ & $1.41(0.12)$ & - & $36.13(1.37)$ \\
\hline 5 & $1,563(175)$ & $2.46(0.05)$ & $63.56(2.11)$ & $0.77(0.08)$ & $1.39(0.12)$ & - & $35.27(1.48)$ \\
\hline 6 & $1,496(173)$ & $2.43(0.05)$ & $61.91(2.08)$ & $0.77(0.08)$ & - & - & - \\
\hline 7 & $1,227(173)$ & $2.47(0.05)$ & $62.56(2.08)$ & - & - & - & - \\
\hline 8 & $1,577(173)$ & $2.47(0.05)$ & $64.34(2.08)$ & - & - & - & - \\
\hline 9 & $1,021(175)$ & $2.50(0.05)$ & $65.27(2.11)$ & - & - & - & - \\
\hline 10 & $1,409(173)$ & $2.52(0.05)$ & $64.24(2.08)$ & - & - & - & - \\
\hline 30 & $1,109(173)$ & $2.54(0.05)$ & $77.28(2.08)$ & - & - & - & - \\
\hline 60 & $2,297(173)$ & $2.62(0.05)$ & $67.65(2.08)$ & - & - & - & - \\
\hline 90 & $2,708(173)$ & $2.64(0.05)$ & $65.89(2.08)$ & - & - & - & - \\
\hline 150 & $2,907(187)$ & $2.68(0.05)$ & $59.92(2.20)$ & - & - & - & - \\
\hline 300 & $517(200)$ & $2.62(0.05)$ & $71.68(2.27)$ & - & $1.63(0.13)$ & - & - \\
\hline
\end{tabular}

${ }^{1} 5$-HT $=$ serotonin $(5$-hydroxytryptamine) PTHrP $=$ parathyroid hormone-related protein

${ }^{2} \mathrm{DRTP}=$ day relative to parturition \pm 0 for $\mathrm{d}-5$ to $10 ; \pm 2$ for $\mathrm{d} 30,60,90,150$, and 300 . 
A

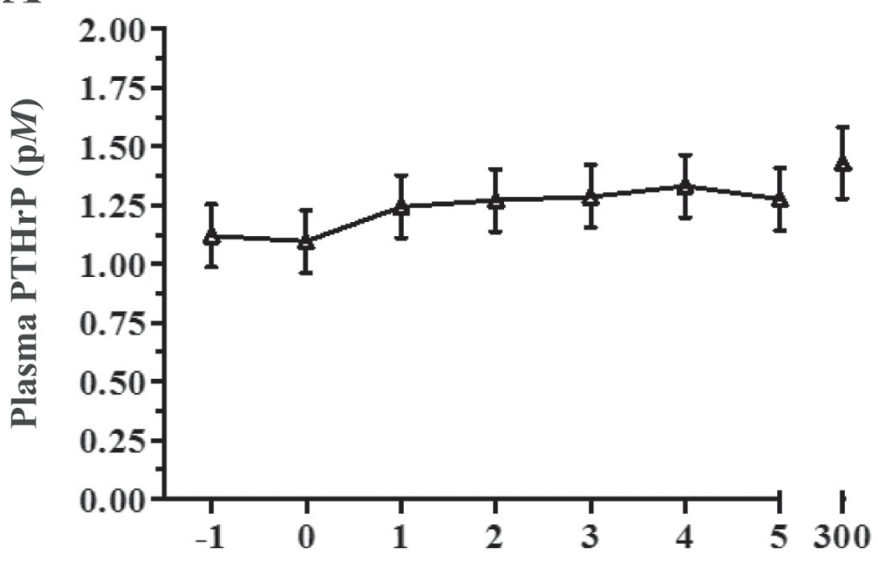

B

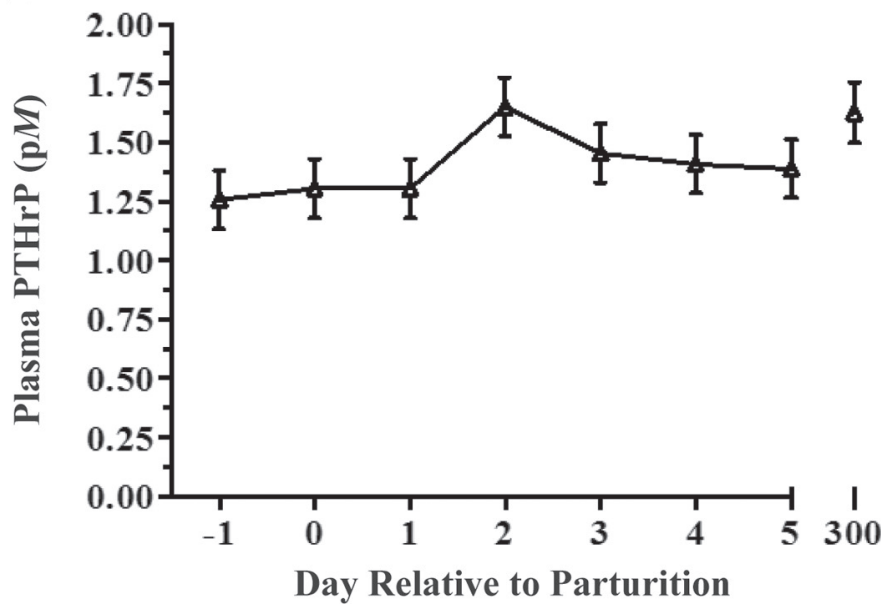

Figure 2. Patterns of circulating plasma parathyroid hormone related-protein (PTHrP) in lactating dairy cows. (A) Farm 1: a significant increase in PTHrP was observed from $\mathrm{d} 1$ to $2(1.24 \pm 0.13$ to $1.27 \pm 0.13 \mathrm{p} M ; P=0.03)$. The concentration in d 0 was less than that on $\mathrm{d} 2$ to $4(P \leq 0.05)$. No difference was observed from d 2 to $5(P \geq 0.43)$. Concentrations of PTHrP reached $1.46 \pm 0.11 \mathrm{p} M$ at $\mathrm{d}$ 300 , a value greater than on all other days except d $2(P=0.06)$. (B) Farm 2: a significant increase in PTHrP was observed from d 1 to 2 as PTHrP increased from $1.30 \pm 0.12$ to $1.65 \pm 0.12 \mathrm{p} M(P<0.0001)$. A significant decline was observed from d 2 to $4(P=0.002)$. Error bars represent SEM.

An additional increase was observed on d 60 compared with d $30(66.69 \pm 1.71 \mathrm{mg} / \mathrm{dL} ; P=0.02$; Table 1$)$. Circulating plasma glucose concentrations were not different on d $90(P=0.59)$ than on d 60. Day 150 glucose decreased compared with that on d $60(P=$ $0.02)$ and tended to be less than on d $90(P=0.06)$. The concentration on d $300(73.03 \pm 2.25 \mathrm{mg} / \mathrm{dL})$ was significantly higher than all other measurements $(P \leq$ $0.0353)$ excluding $\mathrm{d}-5$ and $\mathrm{d}-3$ through $\mathrm{d} 0(P \geq$ 0.1044; Table 1).

The peak circulating plasma glucose concentration on farm 2 was observed on d $0(82.71 \pm 2.14 \mathrm{mg} / \mathrm{dL})$ and was greater than all other measurements $(P \leq$
$0.03)$ excluding those on $\mathrm{d} 30$ and $300(P \geq 0.22$; Table 2 ). Concentrations declined until the transition period nadir, which was recorded on d $4(60.68 \pm 2.08 \mathrm{mg} / \mathrm{dL})$ (Figure 1B; Table 2). Day 4 circulating plasma glucose concentration was less than that on $\mathrm{d}-5$ through $\mathrm{d} 2$ $(P \leq 0.02)$. Plasma glucose was also not different from d 5 through $7(P \geq 0.1550)$ and tended to be less than that on $\mathrm{d} 8$ through $10(P \leq 0.08)$. Circulating plasma glucose was greater on $\mathrm{d} 30$ than on $\mathrm{d} 1$ through 10 $(P \leq 0.002)$. Circulating plasma glucose concentrations declined from d 60 to $90(P=0.01)$. On d 300, circulating plasma glucose concentrations increased to $71.68 \pm$ $2.27 \mathrm{mg} / \mathrm{dL}$, which was elevated compared with that on $\mathrm{d}-3$, d 1 through 10 , d 90, and d $150(P \leq 0.05$; Table 2).

\section{Blood Plasma PTHrP}

Postpartum blood plasma PTHrP increased $(P=$ $0.32)$ on farm 1 from d $1(1.24 \pm 0.13 \mathrm{p} M)$ to $\mathrm{d} 2(1.27$ $\pm 0.13 \mathrm{p} M$; Figure 2A, Table 1$)$. The lowest recorded PTHrP concentration $(1.01 \pm 0.16 \mathrm{p} M)$ was on $\mathrm{d} 0$, which was lower than that on d 2 through $4(P \leq 0.05$; Table 1). No time effect was observed when comparing d 2 through $5(P \geq 0.43)$. Plasma PTHrP was also measured at d $300(1.46 \pm 0.11 \mathrm{p} M$; Table 1$)$, when the value was greater $(P \leq 0.04)$ than that of all measurements in early lactation except that on d $2(P=0.06)$.

A peak PTHrP concentration of $1.65 \pm 0.12 \mathrm{p} M$ was recorded on d 2 postpartum on farm 2 (Figure 2B; Table 2). This level was significantly greater than PTHrP nadir on $\mathrm{d}-1(1.26 \pm 0.12 \mathrm{p} M ; P<0.0001$; Table 2). The peak PTHrP concentration on $\mathrm{d} 2$ was also greater than the subsequent measurements on $\mathrm{d} 4$ and $5(P \leq 0.002)$. The $\mathrm{d} 300$ average of $1.63 \pm 0.13 \mathrm{p} M$ was greater than that measured $\mathrm{d}-1$ through $\mathrm{d} 1$ and on d $5(P \leq 0.40$; Table 2$)$.

\section{Blood Serum BHBA}

No time effect was observed for blood serum BHBA concentrations on farm $1(P=0.21)$. The BHBA concentrations on $\mathrm{d} 4,5$, and 6 were $0.65 \pm 0.05,0.70 \pm$ $0.05,0.73 \pm 0.05 \mathrm{mM}$, respectively (Table 1 ).

Similar to farm 1, no time effect was observed in the daily measurements of BHBA on farm $2(P=0.68)$. The BHBA concentrations on $\mathrm{d} 4,5$, and 6 , were 0.74 $\pm 0.07,0.77 \pm 0.07$, and $0.77 \pm 0.07 \mathrm{mM}$, respectively (Table 2).

\section{Milk Serotonin}

Four daily samples from the transition period were measured on farms 1 and 2 for whole-milk 5-HT con- 
centration. Farm 1 observed a peak milk 5-HT concentration in the colostrum on d $0(1.76 \pm 0.28 \mathrm{ng} / \mathrm{mL})$ (Table 1). Milk 5-HT significantly declined from d 1 $(1.66 \pm 0.17 \mathrm{ng} / \mathrm{mL})$ to $\mathrm{d} 2(1.15 \pm 0.16 \mathrm{ng} / \mathrm{mL} ; P=$ 0.05; (Figure 3A, Table 1). Of the days evaluated, d 3 was the milk 5 -HT nadir with a concentration of 1.01 $\pm 0.16 \mathrm{ng} / \mathrm{mL}$, which was less than on $\mathrm{d} 0$ and $1(P \leq$ 0.02; Table 1).

Farm 2 had an average milk 5-HT concentration on d 0 of $6.13 \pm 0.39 \mathrm{ng} / \mathrm{mL}$ (Table 2). Milk 5 -HT values significantly declined daily in the subsequent $3 \mathrm{~d}$ measured $(P \leq 0.01$; Figure 3B). The milk 5 -HT nadir for the 4 -d sample period was recorded on d $3(1.94 \pm 0.34$ $\mathrm{ng} / \mathrm{mL}$; Table 2).

\section{Milk Total Ca}

Whole-milk total Ca concentration peaked on $\mathrm{d} 1$ on farm 1 (57.42 $\pm 1.77 \mathrm{mM}$; Table 1$)$. No time effect $(P=0.15)$ was observed when comparing colostrum $\mathrm{Ca}(51.09 \pm 3.77 \mathrm{mM})$ collected on d 0 to 1 (Table 1$)$. Milk total Ca tended to decline from d 1 to 2 (46.93 $\pm 1.71 \mathrm{~m} M ; P=0.06$; Figure $3 \mathrm{~A}$, Table 1 ). A decline in milk total $\mathrm{Ca}$ concentration was observed from d 2 to $3(41.09 \pm 1.66 \mathrm{mM} ; P<0.0001)$ and from $\mathrm{d} 3$ to 4 $(38.46 \pm 1.70 ; P=0.01$; Table 1$)$. No time effect was observed in milk total Ca concentrations from d 4 to 5 $(P=0.12)$.

Milk total Ca peaked in colostrum (d 0) on farm 2 (59.88 $\pm 1.66 \mathrm{mM}$; Table 2). No time effect was observed between $\mathrm{d} 0$ and $1(55.46 \pm 1.40 \mathrm{mM} ; P=0.1319$; Table 2). A subsequent daily decline was observed from d 1 to $2(46.93 \pm 1.71 \mathrm{mM} ; P<0.0001)$ and from d 2 to $3(41.09 \pm 1.66 ; P<0.0001$; Figure $3 \mathrm{~B}$, Table 2$)$. No time effect was observed from d 3 to $5(P \geq 0.2874)$.

\section{Correlation Analysis}

Pearson correlation coefficients (r) were calculated for circulating serum 5-HT and circulating total Ca, and for circulating 5-HT and circulating plasma glucose on both farms. The data points were separated into physiologically relevant periods. Correlation coefficients were calculated for the prepartum period $(\mathrm{d}-5$ to -1$)$, d 0 (day of calving), d 1 postpartum, d 2 postpartum, d 1 to 5 postpartum, d 6 to 10 postpartum, mid lactation (d 30 to 150), late lactation (d 300), and for the entire lactation. Correlation analysis for milk 5-HT and milk total Ca was also evaluated for d 0 to 3 on both farms.

On farm 1, we detected a significant overall correlation between serum 5-HT and serum total $\mathrm{Ca}(\mathrm{r}=$ $0.28 ; P<0.0001)$. Significant correlations were also observed on d 1 to $5(\mathrm{r}=0.31 ; P=0.0003$; Figure $4 \mathrm{~A})$ and $\mathrm{d} 6$ to 10 postpartum $(\mathrm{r}=0.22 ; P=0.008$; Figure
4B). We did not observe a significant correlation for the individual days d 0 or 2 of lactation $(P>0.05)$. There was a significant positive correlation for 5-HT and $\mathrm{Ca}$ on $\mathrm{d} 1(\mathrm{r}=0.57 ; P=0.002)$. Farm 1 did not have any significant correlations between serum 5-HT and serum total $\mathrm{Ca}$ at later points in lactation and did not exhibit a significant correlation between milk 5-HT and milk total $\mathrm{Ca}(P=0.33)$. A significant negative correlation between circulating 5 -HT and glucose was only observed on d 1 to $\mathrm{d} 5(\mathrm{r}=-0.21 ; P=0.018$; Figure 5A).

Farm 2 had a significant positive correlation between circulating 5-HT and total $\mathrm{Ca}$ over the entire lactation $(\mathrm{r}=0.13 ; P=0.0008)$. A positive correlation was observed on farm 2 from d 6 to $10(\mathrm{r}=0.16 ; P=0.045$; Figure 4C) for circulating serum 5-HT and circulating total Ca. However, neither of these significant correlations were strong values, despite the entire lactation correlation being very significant. We did not observe a significant correlation on d 0 or 2 between 5 -HT and $\mathrm{Ca}(P>0.05)$. However, we did detect a tendency for a positive correlation on $\mathrm{d} 1$ postpartum $(\mathrm{r}=0.29 ; P$ $=0.09$ ). No significant correlations were observed at any other points in lactation between circulating 5 -HT and total Ca. A positive milk 5-HT and milk Ca correlation was present on farm $2(\mathrm{r}=0.34 ; P=0.0002$; Figure $3 \mathrm{C}$ ). Serotonin and circulating plasma glucose were negatively correlated during mid-lactation (d 30 to $150 ; \mathrm{r}=-0.26 ; P=0.002$; Figure $5 \mathrm{~B}$ ).

\section{DISCUSSION}

Maintaining Ca homeostasis is a challenge for dairy cows during the transition from pregnancy to lactation. The cost associated with treating hypocalcemia and the increased risk of numerous other transition-related disorders leads to the current demand for further research of disease mitigation methods (Goff and Horst, 1997; Goff, 2008; Reinhardt et al., 2011). The utilization of a DCAD and aggressive treatment in early lactation with exogenous sources of Ca has dampened the effects of hypocalcemia, but limitations remain (Block, 1984; Wu et al., 2008; Martinez et al., 2014). Serotonin is implicated in the increase of PTHrP production by the mammary gland, as well as increased expression of $\mathrm{Ca}$ and glucose transporters in the mammary epithelium in rodent models (Hernandez et al., 2012; Laporta et al., 2013a,b).

Interestingly, circulating 5-HT declined at parturition on both farms, similarly to total Ca (Figure 1). We previously observed a similar pattern of 5-HT around the time of calving in a much smaller experiment (Laporta and Hernandez, 2015). We found a positive correlation between circulating serum 5-HT and total Ca observed 


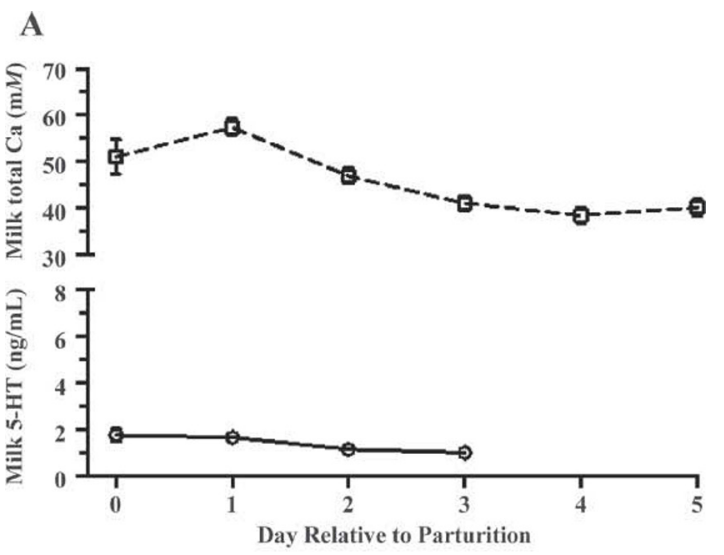

B
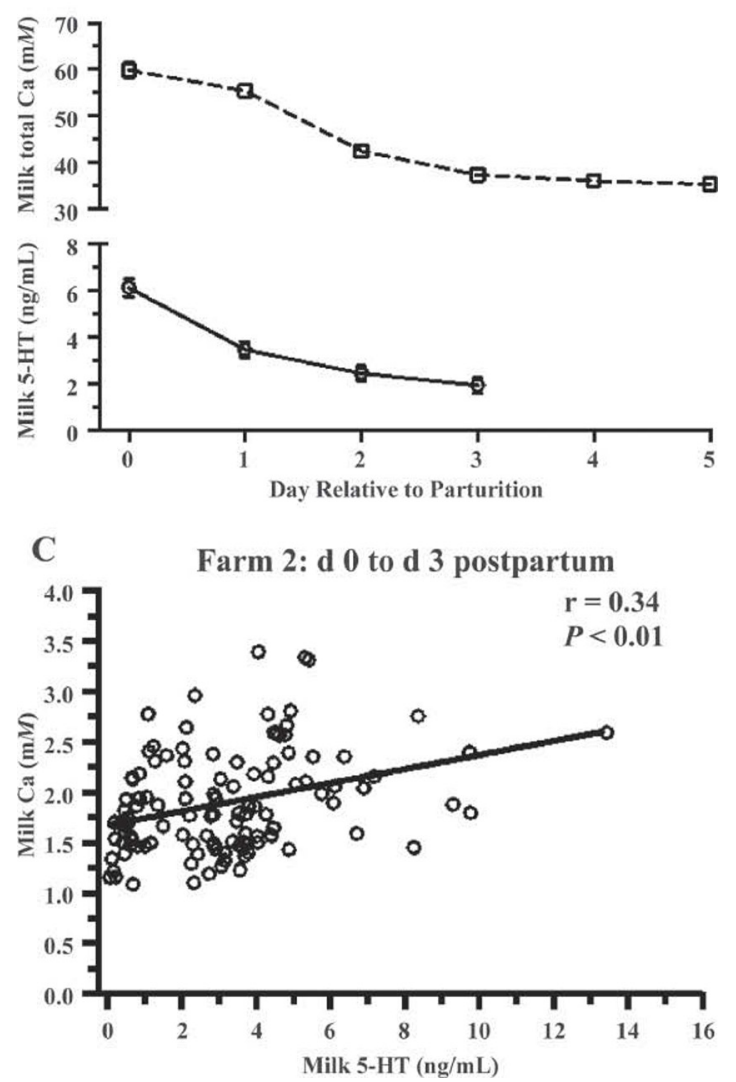

Figure 3. Patterns of milk serotonin (5-HT) and milk calcium (Ca) in lactating dairy cows. (A) Farm 1 cows showed a significant decline $(P=0.05)$ in milk 5 -HT from d $1(1.66 \pm 0.17 \mathrm{ng} / \mathrm{mL})$ to $\mathrm{d} 2(1.15 \pm$ $0.16 \mathrm{ng} / \mathrm{mL})$; peak milk 5 -HT was observed on d $0(1.76 \pm 0.28 \mathrm{ng} /$ $\mathrm{mL})$. Milk Ca tended to decline daily from d $1(57.42 \pm 1.77 \mathrm{mM})$ to $\mathrm{d}$ $2(46.93 \pm 1.71 \mathrm{~m} M ; P<0.06)$. Milk Ca significantly declined from d 2 to 3 and from d 3 to $4(P \leq 0.01)$. Milk 5 -HT and milk total Ca were not correlated $(P>0.10)$. $(\overline{\mathrm{B}})$ A significant decrease of milk 5 -HT was seen daily on farm $2(P<0.01)$, declining from $6.13 \pm 0.39$ to $1.94 \pm$ $0.34 \mathrm{ng} / \mathrm{mL}$ within the first $4 \mathrm{~d}$ of lactation. Peak milk total Ca was observed on d $0(59.88 \pm 1.66 \mathrm{mM})$. Milk Ca declined significantly from d $1(55.46 \pm 1.40 \mathrm{mM})$ to $\mathrm{d} 2(42.55 \pm 1.37 \mathrm{mM})$ and from d 2 to $3(37.32 \pm 1.41 \mathrm{mM})(\mathrm{C})$ Circles represent milk 5-HT and milk total Ca values for each day during d 0 to 3 relative to parturition period on farm 2. Milk 5-HT and milk total Ca were positively correlated on farm 2 from d 0 to 3 of lactation $(\mathrm{r}=0.34 ; P=0.0002)$. Error bars represent SEM. over the course of the entire lactation, and on $\mathrm{d} 1$ to 5 on farm 1 and from d 6 to 10 on farm 2, although the latter correlation was not nearly as strong as that observed on farm 1 (Figure 4A, B). The lack of a correlation between 5 -HT and $\mathrm{Ca}$ from d 1 to 5 on farm 2 could be due to the parity distribution on the farms, with farm 2 have more second-lactation cows $(57 \%$ of cows enrolled) than other parities and farm 1 having more third-lactation cows $(53 \%)$ enrolled than other parities; however, other factors related to management, such as aggressive treatment with oral calcium boluses postcalving, which occurred on farm 2 but not on farm 1 , may account for this result. The strongest correlation between serum 5-HT and Ca was on d 1 of lactation on both farms. This observation supports the hypothesis that 5-HT may have a biological role in Ca regulation. Furthermore, this finding supports our previous data in which 5-HT and total Ca were positively correlated on d 1 of lactation (Laporta et al., 2013c). The temporal mappings of 5-HT and total Ca over the lactation cycle mirror each other closely, particularly around the time of calving, as reflected by a positive correlation of 5-HT and Ca over the entire lactation cycle; however, we have not determined how Ca responds to changes in 5-HT or vice versa. These results suggest that the physiological mechanisms downstream of 5 -HT and $\mathrm{Ca}$ may be interrelated, but this should be directly tested to determine how changing 5-HT or Ca might affect the other in the dairy cow. Previous results in rodents indicate that manipulation of 5-HT around parturition improves calcium homeostasis (Laporta et al., 2013b); however, this has not been tested in dairy cows and should be further explored.

Milk 5-HT was measured to evaluate mammary gland contribution to the 5-HT supply on d 0, 1, 2, and 3 milk only. These days were selected because milk 5 -HT was not detectable in mature milk (Hernandez et al., 2009; Laporta et al., 2014). Additionally, it may be of interest to investigate the interactions of 5-HT with parathyroid hormone and vitamin $\mathrm{D}$, as these hormones are critical in maintaining $\mathrm{Ca}$ homeostasis in a lactating dairy cow and we are unaware of the role that 5-HT plays with these hormones (Goff, 2008).

On both farms, plasma glucose levels declined postpartum (Figure 1A, B). This decline was consistent with the inability of the cows to maintain circulating plasma glucose levels postpartum, which leads to development of a NEB, along with increased production of milk by the cow (Grummer, 1995). A negative correlation was detected between circulating 5 -HT and glucose concentrations on $\mathrm{d} 1$ to 5 on farm 1 ( $\mathrm{r}=-0.21 ; P=0.018$; Figure 5A). This was surprising based on our previous findings that circulating 5 -HT on d 1 of lactation was negatively correlated with ketosis severity (Laporta et 
A

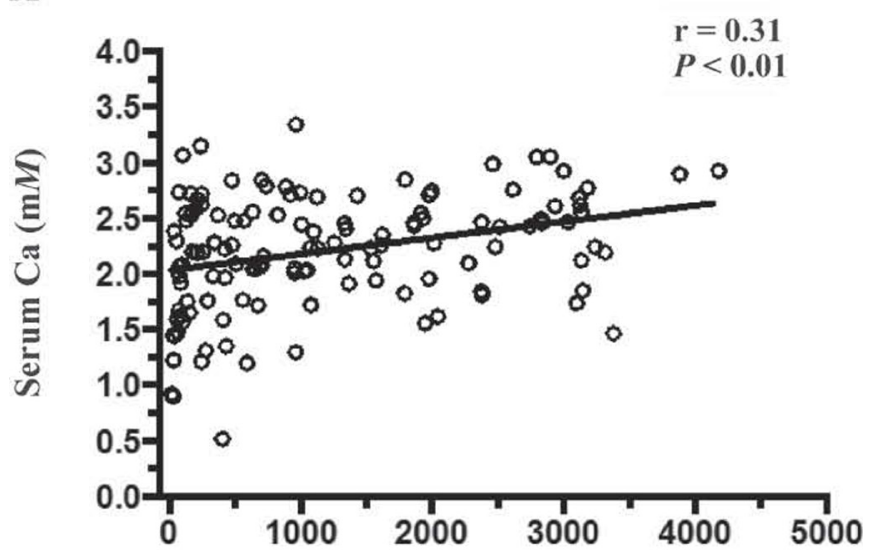

B

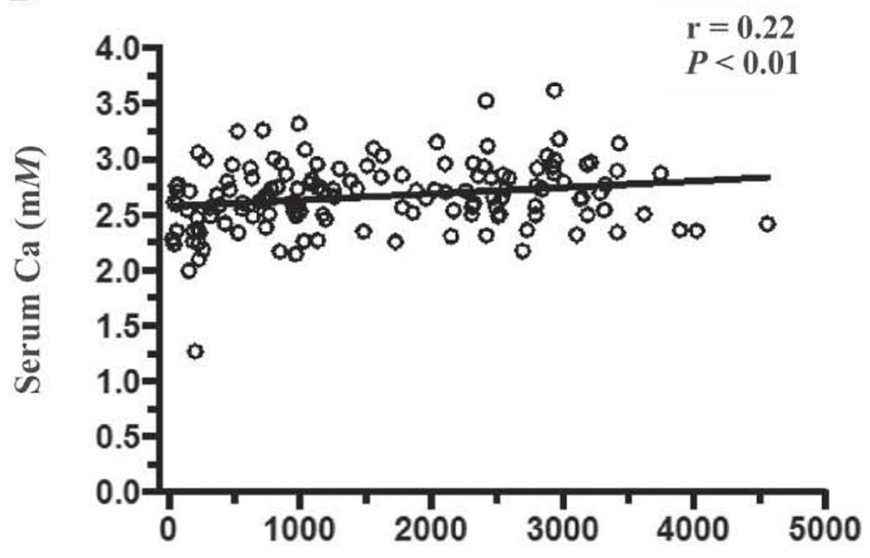

C

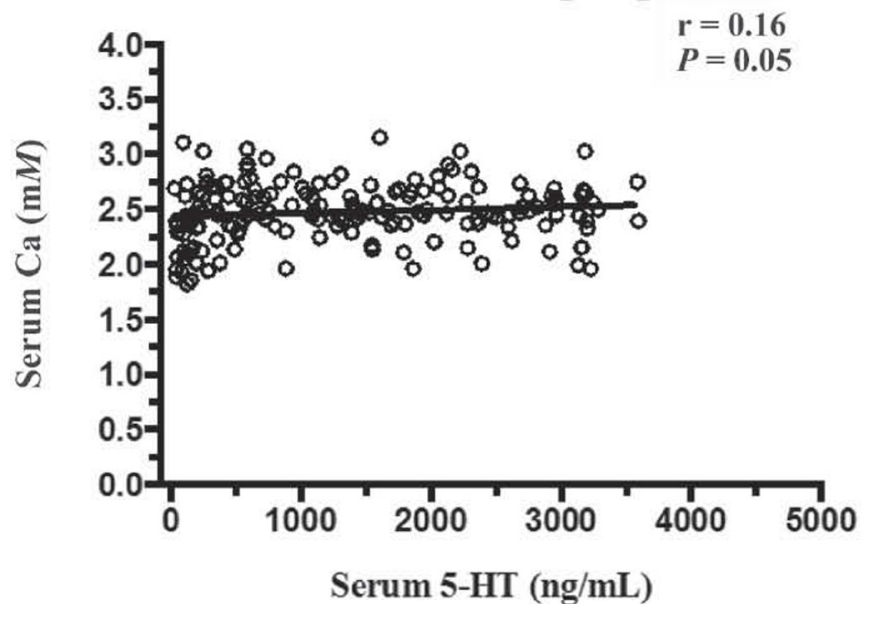

Figure 4. Correlation of serum serotonin (5-HT) and serum Ca in multiparous dairy cows during early lactation. Circles represent the circulating serum 5-HT and the corresponding circulating serum Ca values for each day with a significant positive correlation on (A) farm 1 from d 1 to 5 postpartum $(\mathrm{r}=0.31 ; P<0.01)$, (B) farm 1 from $\mathrm{d} 6$ to 10 postpartum $(\mathrm{r}=0.22 ; P<0.01)$, and $(\mathrm{C})$ farm 2 from $\mathrm{d} 6$ to 10 postpartum $(\mathrm{r}=0.16 ; P<0.01)$. al., 2013c). However, based on the BHBA concentrations recorded on $\mathrm{d} 4$ through 6 , the cows were not in the subclinical or clinical range for ketosis (McArt et al., 2012). This could explain the observed negative correlation between 5-HT and glucose during the early lactation period. On farm 2, a negative correlation between 5-HT and glucose was observed during mid-lactation (Figure 5B). Serotonin signals through a variety of receptors, of which the bovine mammary gland alone has 5 (Hernandez et al., 2009). This suggests that 5-HT may govern a variety of physiological functions during lactation that have yet to be explored, and that this may differ based on stage of lactation. Furthermore, research has demonstrated that increasing 5 -HT during
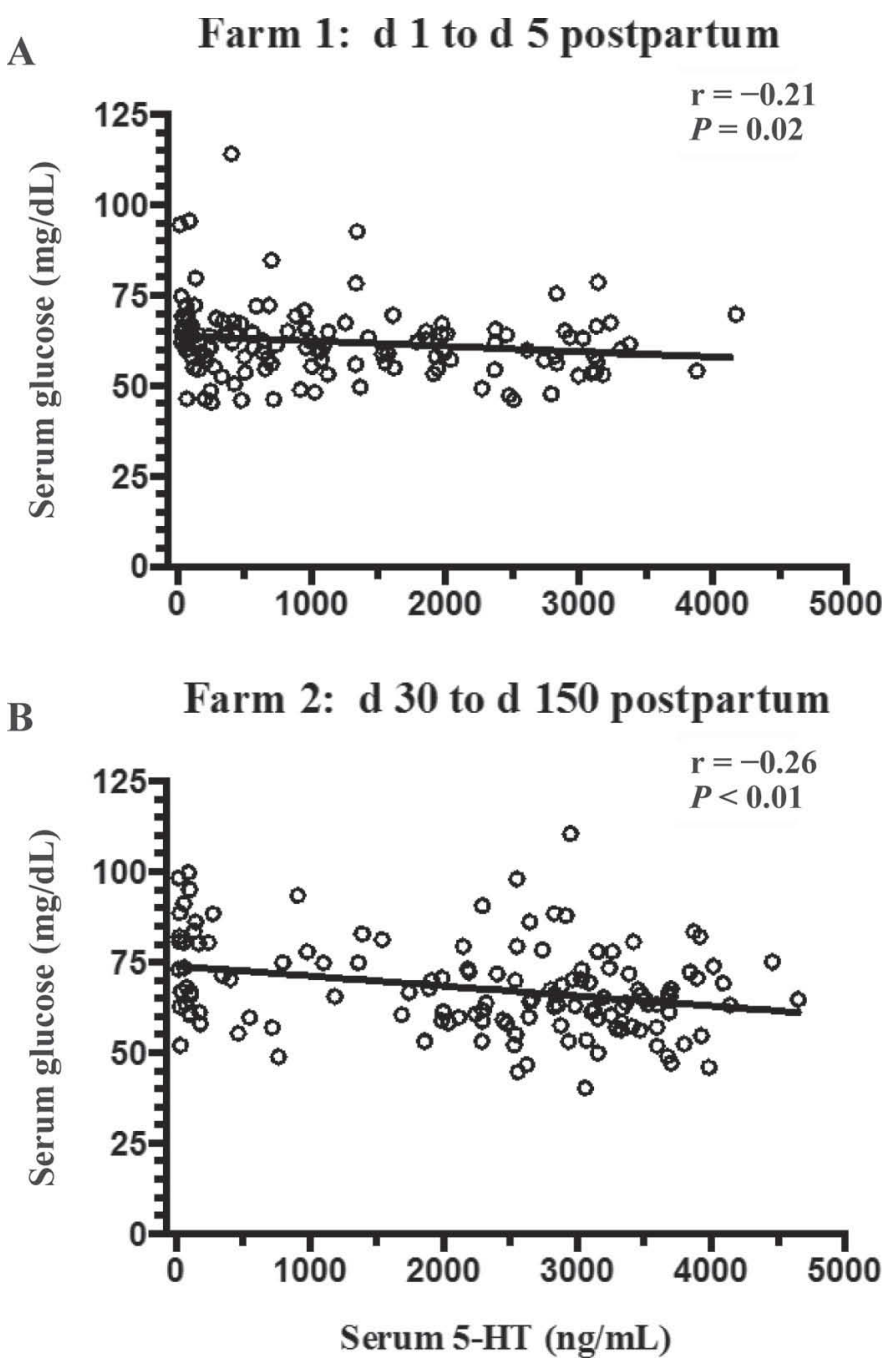

Figure 5. Correlation of circulating serum serotonin (5-HT) and circulating plasma glucose in dairy cows. Circles represent circulating serum 5-HT and the corresponding circulating plasma glucose values for each day with a significant negative correlation observed on (A) farm 1 from d 1 to 5 postpartum $(\mathrm{r}=-0.21 ; P<0.02)$, and (B) farm 2 from d 30 to $150(\mathrm{r}=-0.26 ; P<0.01)$. 
the transition period in rats improves gluconeogenesis in the liver and energy sensing by the mammary gland (Laporta et al., 2013a). Future research exploring this relationship should be conducted to compare healthy and ketotic cows to determine if 5 -HT is important in the regulation of glucose homeostasis during the early postpartum period.

The significant decrease in circulating blood serum 5-HT on both farms on d 300 (Figure 1A, B; Table 1-2) is interesting, considering the role of 5 - $\mathrm{HT}$ as a regulator of mammary gland involution (Pai and Horseman, 2008; Hernandez et al., 2011). However, as our focus was the peripartum period, limited sampling was done during this period and future research should focus on thoroughly exploring the role of 5-HT around dry off.

Before this investigation, little was known about the temporal pattern of 5-HT in the dairy cow. The data presented in this study clearly indicate that 5-HT may be involved in Ca homeostasis in the dairy cow, as previously demonstrated in rodent models; however, the exact mechanisms remain unclear in dairy cows. The data obtained in this experiment lend support for future research that delineates the role of 5-HT in regulating $\mathrm{Ca}$ and glucose homeostasis in the dairy cow and the exact mechanisms governing their interactions. Future controlled experiments should focus on how changes in circulating 5-HT affect $\mathrm{Ca}$, and vice versa. Additionally, these concepts should be explored in terms of glucose homeostasis.

\section{CONCLUSIONS}

Serotonin changed dynamically prepartum through the end of lactation, particularly on farm 1. A positive correlation between circulating 5-HT and circulating total $\mathrm{Ca}$ was detected on both farms in multiparous cows for the entire lactation, from d 1 and 5 on farm 1 , and from d 6 to 10 on farm 2; however, the correlation was not strong on farm 2 . In addition, milk 5-HT concentrations were greater in colostrum than in milk and on farm 2 than farm 1 . Serotonin and glucose were negatively correlated during the early lactation period on farm 1 and during mid lactation on farm 2. Future research should explore the effects of manipulating the 5-HT axis on $\mathrm{Ca}$ and glucose metabolism in dairy cattle.

\section{REFERENCES}

Adams, R., V. Ishler, and D. Moore. 1996. Trouble-shooting milk fever and downer cow problems. DAS 96-27. IVE1f. PENpages 2890216:1-7

Block, E. 1984. Manipulating dietary anions and cations for prepartum dairy cows to reduce incidence of milk fever. J. Dairy Sci. 67:2939-2948.
Chabbi-Achengli, Y., A. E. Coudert, J. Callebert, V. Geoffroy, F Côté, C. Collet, and M. C. de Vernejoul. 2012. Decreased osteoclastogenesis in serotonin-deficient mice. Proc. Natl. Acad. Sci. USA 109:2567-2572.

Czerniewicz, M., K. Kielczewska, and A. Kruk. 2006. Comparison of some physicochemical properties of milk from Holstein-Friesian and Jersey cows. Polish J. Food Nutr. Sci. 15:61-64.

Goff, J. P. 2008. The monitoring, prevention, and treatment of milk fever and subclinical hypocalcemia in dairy cows. Vet. J. 176:50-57.

Goff, J. P., and R. L. Horst. 1997. Physiological changes at parturition and their relationship to metabolic disorders. J. Dairy Sci. $80: 1260-1268$

Grummer, R. R. 1995. Impact of changes in organic nutrient metabolism on feeding the transition dairy cow. J. Anim. Sci. 73:28202833.

Hernandez, L. L., J. L. Collier, A. J. Vomachka, R. J. Collier, and N. D. Horseman. 2011. Suppression of lactation and acceleration of involution in the bovine mammary gland by a selective serotonin reuptake inhibitor. J. Endocrinol. 209:45-54.

Hernandez, L. L., K. A. Gregerson, and N. D. Horseman. 2012. Mammary gland serotonin regulates parathyroid hormone-related protein and other bone-related signals. Am. J. Physiol. Endocrinol. Metab. 302:E1009-E1015.

Hernandez, L. L., S. W. Limesand, J. L. Collier, N. D. Horseman, and R. J. Collier. 2009. The bovine mammary gland expresses multiple functional isoforms of serotonin receptors. J. Endocrinol. 203:123-131.

Karkalas, J. 1985. An improved enzymic method for the determination of native and modified starch. J. Sci. Food Agric. 36:1019-1027.

Laporta, J., J. J. Gross, T. D. Crenshaw, R. M. Bruckmaier, and L. L. Hernandez. 2014. Short Communication: Timing of first milking affects serotonin (5-HT) concentrations. J. Dairy Sci. 97:29442948.

Laporta, J., and L. L. Hernandez. 2015. Serotonin receptor expression is dynamic in the liver during the transition period in Holstein dairy cows. Domest. Anim. Endocrinol. 51:65-73. http://dx.doi. org/10.1016/j.domaniend.2014.11.005.

Laporta, J., T. L. Peters, K. E. Merriman, C. M. Vezina, and L. L. Hernandez. 2013a. Serotonin (5-HT) affects expression of liver metabolic enzymes and mammary gland glucose transporters during the transition from pregnancy to lactation. PLoS ONE 8:e57847.

Laporta, J., T. L. Peters, S. R. Weaver, K. E. Merriman, and L. L. Hernandez. 2013b. Feeding 5-hydroxy-L-tryptophan during the transition from pregnancy to lactation increases calcium mobilization from bone in rats. Domest. Anim. Endocrinol. 44:176-184.

Laporta, J., S. A. E. Moore, M. W. Peters, T. L. Peters, and L. L. Hernandez. 2013c. Short communication: Circulating serotonin (5HT) concentrations on day 1 of lactation as a potential predictor of transition-related disorders. J. Dairy Sci. 96:5146-5150.

Lean, I. J., P. J. DeGaris, D. M. McNeil, and E. Block. 2006. Hypocalcemia in dairy cows: Meta-analysis and dietary cation anion difference theory revisited. J. Dairy Sci. 89:669-684.

Martinez, N., L. D. P. Sinedino, R. S. Bisinotto, R. Daetz, G. C. Gomes, L. F. Greco, W. W. Thatcher, C. A. Risco, and J. E. P. Santos. 2014. Effects of oral calcium supplementation on body temperature, incidence of uterine diseases, and milk yield in dairy cows. J. Anim. Sci. 92(E-Suppl.2):441. (Abstr.)

Matsuda, M., T. Imaoka, A. J. Vomachka, G. A. Gudelsky, Z. Hou, M. Mistry, J. P. Bailey, K. M. Nieport, D. J. Walther, M. Bader, and N. D. Horseman. 2004. Serotonin regulates mammary gland development via an autocrine-paracrine loop. Dev. Cell 6:193-203.

McArt, J. A. A., D. V. Nydam, and G. R. Oetzel. 2012. Epidemiology of subclinical ketosis in early lactation dairy cattle. J. Dairy Sci. 95:5056-5066.

NRC. 2001. Nutrient Requirements of Dairy Cattle. 7th rev. ed. Natl Acad. Press, Washington, DC.

Pai, V. P., and N. D. Horseman. 2008. Biphasic regulation of mammary epithelial resistance by serotonin through activation of multiple pathways. J. Biol. Chem. 283:30901-30910. 
Reinhardt, T. A., J. D. Lippolis, B. J. McCluskey, J. P. Goff, and R. L. Horst. 2011. Prevalence of subclinical hypocalcemia in dairy herds. Vet. J. 188:122-124.

Rortvedt, L. A., and T. D. Crenshaw. 2012. Expression of kyphosis in young pigs is induced by a reduction of supplemental vitamin D in maternal diets and vitamin $\mathrm{D}, \mathrm{Ca}$, and $\mathrm{P}$ concentrations in nursery diets. J. Anim. Sci. 90:4905-4915.

Stull, M. A., V. Pai, A. J. Vomachka, A. M. Marshall, G. A. Jacob, and N. D. Horseman. 2007. Mammary gland homeostasis employs serotonergic regulation of epithelial tight junctions. Proc. Natl. Acad. Sci. USA 104:16708-16713.
Wu, W. X., J. X. Liu, G. Z. Xu, and J. A. Ye. 2008. Calcium homeostasis, acid-base balance, and health status in periparturient Holstein cows fed diets with low cation-anion difference. Livest. Sci. 117:7-14.

Wysolmerski, J. J. 2002. The evolutionary origins of maternal calcium and bone metabolism during lactation. J. Mammary Gland Biol. Neoplasia 7:267-276.

Wysolmerski, J. J. 2010. Interactions between breast, bone, and brain regulate mineral and skeletal metabolism during lactation. Ann. N. Y. Acad. Sci. 1192:161-169. 